Culture of Accidents 



\author{
Michael Witmore
}

\title{
Culture of Accidents
}

Unexpected Knowledges

in Early Modern England

Stanford University Press

Stanford, California 2001 
Stanford University Press

Stanford, California

(C) 2001 by the Board of Trustees of the

Leland Stanford Junior University

Printed in the United States of America

Library of Congress Cataloging-in-Publication Data

Witmore, Michael

Culture of accidents : unexpected knowledges in early modern

England / Michael Witmore.

p. $\mathrm{cm}$.

Includes bibliographical references and index.

ISBN 0-8047-3556-5 (cloth : alk. paper)

1. Accidents-History. 2. Philosophy, English. I. Title.

BD701.W44 2001

$111^{\prime} 1-\operatorname{dc} 21$

2001040028

$\mathrm{CIP}$

Original printing 2001

Last figure below indicates year of this printing:

$\begin{array}{llllllllll}10 & 09 & 08 & 07 & 06 & 05 & 04 & 03 & 02 & 01\end{array}$

Typeset at Stanford University Press in 10/13 Palatino 